\title{
Cultural Diplomacy as a Tool of Ukraine's Foreign Policy: Institutional Dimension
}

\author{
Dyplomacja kulturalna jako narzędzie polityki zagranicznej Ukrainy: \\ wymiar instytucjonalny
}

\section{- Abstrakt •}

W artykule omówiono ważną rolę dyplomacji kulturalnej jako wektora polityki zagranicznej i jej miejsce wśród narzędzi dyplomacji publicznej. Skoncentrowano się na analizie potencjału dyplomacji kulturalnej w ukraińskiej działalności zagranicznej. Rozważa się zwłaszcza instytucjonalne aspekty promocji kultury ukraińskiej za granicą. Szczególną uwagę poświęca się Instytutowi Ukraińskiemu, utworzonemu w 2017 roku pod auspicjami Ministerstwa Spraw Zagranicznych. Ponieważ przez wiele lat rządowi brakowało pełnej uwagi dyplomacji kulturalnej, pojawiły się prywatne inicjatywy w tej dziedzinie. Otrzymawszy wsparcie od MSZ i misji dyplomatycznych Ukrainy, stały się częścią mechanizmu dyplomacji kulturalnej kraju.

Słowa kluczowe: dyplomacja kulturalna; dyplomacja publiczna; polityka zagraniczna; Ukraina

\section{- Abstract •}

The present paper considers the essential role of cultural diplomacy as a foreign policy vector and discusses its place among the tools of public diplomacy. The emphasis is placed on analysing the potential of cultural diplomacy in the Ukrainian foreign policy activities. In particular, the authors examine institutional aspects of promotion of the Ukrainian culture abroad; special attention is paid to the Ukrainian Institute, established in 2017 under the auspices of the Ministry of Foreign Affairs. As for many years there was no comprehensive governmental approach to cultural diplomacy, private initiatives in the field emerged to fill the gap. Having received some support from the Foreign Affairs Ministry and Ukraine's diplomatic missions, these entities became part of the state's cultural diplomacy mechanisms.

Keywords: cultural diplomacy; public diplomacy; foreign policy; Ukraine 
Active supplementation of and, to some extent, replacement of traditional diplomatic tools with new models allowing for direct communication with target foreign audiences is an integral part of foreign policy of any country aiming to establish itself as a strong international player. This facet of foreign policy is particularly important at a time when winning the favour of foreign public is one of key factors directly contributing to the success of national foreign policy actions.

We can currently observe a transition from traditional diplomacy, or, as defined by R. Ammon (2001), "old diplomacy" - understood as implementation of foreign policy through political contacts between governments - to the so-called "new diplomacy" that relies more on global press and television. Due to introduction of information technology into the practice of diplomacy, new forms of diplomacy and corresponding terms to describe them have emerged, such as "media diplomacy", "network diplomacy", "virtual diplomacy", "real-time diplomacy" and similar. Another area of diplomatic activity undergoing a transformation is the audience, with marked expansion of the range of audiences targeted to establish direct contact with -nowadays the list includes populations of other countries, NGOs, educational institutions etc. The concept of public diplomacy has been introduced; understood as a dialogical communication between governments or other actors in the international relations arena and mass audiences in other countries through mass media and non-mediated channels of contact. The aim of public diplomacy is to create or reinforce a positive image of a given country and its society, to shape positive attitudes toward this country by influence exerted on the public opinion - consequently making international policy goals easier to achieve (Ociepka, 2008, p. 3956).

The role of culture in the practice of public diplomacy is very important. According to Joseph Nye (2004, p. 11), culture is a part of soft power resources, along with the state's institutions, values and policies. As one considers public diplomacy as a platform for implementation of soft power, culture is clearly recognizable as an integral part thereof. Moreover, promotion of culture is often the main goal of public diplomacy practices - and thus cultural diplomacy can be distinguished as a separate, independent vector in public diplomacy activities.

The aim of the present paper is to consider the place of cultural diplomacy in the Ukraine's foreign affairs strategy and analyse what institutions are used in its implementation. Ukraine's cultural diplomacy did not attract much attention from researchers, probably as there was no systemic activity in this domain in the recent years. Currently there are no comprehensive studies focusing on the newly born institutions such as the Ukrainian Institute and the MFA Office of Public Diplomacy. Key sources of information presented in this article are legal acts and 
media coverage of events linked to activities of various cultural diplomacy institutions (both state-owned and private). Overall, the methodology used in the paper is based on case studies and document analysis.

\section{Cultural Diplomacy as Part of Public Diplomacy}

In The Ukrainian Diplomatic Encyclopaedia cultural diplomacy is defined as: 1) foreign cultural policy (culture policy), aimed at preserving national culture, advocating national cultural identity in international cooperation; it combines state policy as concerns specific areas of cultural activities, culture in foreign policy activities, instrumental use of culture and cultural norms in foreign policy actions; 2) consideration of cultural factors in diplomatic activities in order to achieve inter-state agreement by overcoming cultural barriers; 3) use of various elements, such as culture, art and education to protect and internationally promote the state's interests (cit. ex Serbina, Kuchmii, 2011, p. 124).

P. van Ham (2011, p. 115) stated that cultural diplomacy remains at the core of what public diplomacy aims to achieve: reaching the general public and elites in other countries in a way that generates more understanding and support for one's own interests, ideas, and values. However, cultural diplomacy, as well as public diplomacy as a whole, is viewed with caution by some experts, researchers and policy makers. For example, in the historical encyclopaedia of Propaganda and mass persuasion the phenomenon of cultural diplomacy is filed under the heading of "cultural propaganda" and described as a long-term process intended to promote a better understanding of the nation sponsoring a given activity. Examples of activities provided include dissemination of cultural products - films, magazines, radio and television programs, art exhibitions, traveling theatre groups and orchestras - as well as promotion of language teaching and a wide range of educational activities, such as student-exchange schemes. These activities are designed to enhance a nation's image among the populations of other countries, with a view to creating goodwill and influencing the polices of their governments through the pressure of public opinion (Cull et al, 2003, p. 101).

This reserved attitude stems, in our opinion, from several factors. Firstly, the idea of public diplomacy has largely grown out of propagandistic practices that had also focused on directly reaching the target audiences, but had relied more on the use of media and exerting visible influence, imposing certain thoughts, or "brainwashing". In fact, the term "public diplomacy" was initially coined to refer to information campaigns of the US attempting to influence the Soviet Union and 
the socialist bloc during the Cold War. E. Gilboa (2008, p. 59) has defined such activities as the "Basic Cold War model" and differentiated it from other models of public diplomacy.

Secondly, cultural diplomacy is often interpreted as a hidden form of cultural imperialism, and therefore is also treated with caution by many politicians and researchers. Yet somehow the idea of cultural diplomacy has taken root and is present in foreign policies of many countries. The main institutional form of practising cultural diplomacy has traditionally been the establishment of special agencies such as the British Council (UK), Alliance Française (France), Goethe-Institut (Germany), Instytut Adama Mickiewicza (Poland), Instituto Cervantes (Spain) and others.

\section{Role of Cultural Diplomacy in Ukraine's Foreign Policy}

For Ukraine, the need to implement various forms of cultural diplomacy is influenced by several factors. Firstly, Ukraine, as well as other former Soviet and Yugoslav republics, faced the task of (re)forming its identity and ensuring its recognition after gaining independence. While there were prior periods of Ukrainian statehood, it was really the first time that Ukraine emerged as a truly independent state. It was a central problem for Ukraine to separate itself from Russia, often identified with the former USSR as a whole by the ordinary public pretty much everywhere in the world. The importance of this problem was clearly recognized at state level, for example the then-President of Ukraine Leonid Kuchma (2003) published a book eloquently titled Ukraine is not Russia. The author shared his views on Ukraine's past, the events of the $20^{\text {th }}$ century and the most recent years with a consideration given to whether Ukraine could be considered a former Russian colony, and review of the common historical and cultural heritage, as well as differences, problems and mutual "debts". Cultural factors could in this situation play a significant role in formation of the foreign audiences' background knowledge about Ukraine, with presentation of the distinctive Ukrainian culture abroad serving as the main tool and "primer" thereof.

Secondly, implementation of cultural diplomacy strategy in conjunction with other communicative instruments (media diplomacy, nation branding etc.) could contribute to generating support for the Ukrainian foreign policy actions among foreign audiences, which is particularly relevant in the current context of military aggression from Russia. Ukrainian researcher T. Hrachevska (2015, p. 25) noted that risks carried by ignoring cultural diplomacy as a tool and gaps in support- 
ing the related initiatives have been demonstrated over the past two years in the Ukrainian case. Seeing the lack of information about Ukraine in other states, and considering the armed aggression it is suffering, Ukrainian diplomatic missions and cultural institutions should create mechanisms not only to promote the national cultural product, but also to provide truthful information about the chain of events on the Ukrainian territory. This is not simply a matter of creating a positive international image, but rather of homeland security.

Officially, the need to add a cultural component to Ukraine's foreign policy was recognized in 2006. The then-President of Ukraine approved - by Decree 142/2006 - the "Regulation on establishment of the Cultural-informational centres in the structures of Ukraine's foreign diplomatic missions". As main objectives of these centres were proclaimed: to promote international cooperation of Ukraine in the fields of culture, education, science and technology, tourism, physical culture and sports with the mission's host state; to disseminate information about Ukraine in hosting state; to familiarize citizens of receiving countries with the history and culture of Ukraine, to promote Ukrainian language in the territory of these states; to maintain contact with Ukrainians abroad, offering support in meeting their cultural, linguistic, informational and other needs; to disseminate information about tourism opportunities and attractiveness of Ukraine as a tourism destination, to promote cooperation with receiving states in the domain of tourism (Prezydent Ukrainy, 2006). Operation of the centres, according to the above-mentioned Regulation, should be organized by, in addition to the Ministry of Foreign Affairs, also the Ministry of Culture and Tourism of Ukraine, the Ministry of Education and Science of Ukraine, the Ministry for Family, Youth and Sports of Ukraine, and the Ukrainian State Committee for Television and Radio Broadcasting. Nowadays, according to the "List of foreign diplomatic institutions of Ukraine the structures of which include a Cultural-informational centre in their midst", approved in 2006 and amended in 2008 and 2012, 31 cultural-informational centres - with 27 at the diplomatic missions of Ukraine and 4 at Consulates General - are in operation. It should be noted that there are 16 such centres functioning within the diplomatic missions of Ukraine in the EU-member states (see: Kabinet ministriv Ukrainy, 2006).

Meanwhile, expert estimates indicate that activities of these centres are inefficient. For example, the National Institute for Strategic Studies prepared an analytical note "Optimizing the strengthening of Ukraine's cultural presence in Europe" in 2014, stating that the activities of the centres were limited to protocol events or advocacy activities (on the Day of Unification and Freedom of Ukraine, International Mother Language Day, Shevchenko days, etc.), annual celebrations 
of anniversaries, and commemoration of famous Ukrainians, whilst any activities contributing to building long-term relationships and cooperation were rare. Summing up the work of cultural missions of Ukraine in foreign states during the years 2011-2013, the document identified the following trends in their activities: small number of employees and lack of specialists in cultural management on staff, what complicated the task of promoting national Ukrainian culture in the international arena; dissemination of information about Ukraine not conducive to longer-term cultural cooperation prevailing among the activities undertaken by the centres in European countries; disseminated information relating primarily to the history of the Ukrainian people and their traditional culture, with topics such as modern evolution of culture and civil society being overlooked; in most cases, diplomatic agreements between countries limited to standard formal measures such as exchange of delegations, with diplomatic or ministry officials making up the bulk of mission employees, with overall only a simulacrum of real work being done (Rozumna, 2014).

In recent years, most employees in the field of cultural diplomacy are not career diplomats, but culture and public sector activists. In accordance with this trend, Ukrainian writer, singer, journalist and TV presenter Irena Karpa was appointed as the first Culture secretary of the Embassy of Ukraine in France in 2015 (Ukrinform, 2015), and Oleksandra Saenko, another public figure and member of the NGO "Democratic Ukraine" (its representatives actively participated in actions in support of Ukraine in Austria, for example sharing in the local media their perspective on events in the Crimea and Eastern Ukraine, confronting Russian propaganda) was appointed as a cultural attaché to the Embassy of Ukraine in Austria (Rohovyk, 2016).

It was only recently that the Ministry of Foreign Affairs of Ukraine has increased its interest in public and, in particular, cultural diplomacy. Thus, the First Cultural Diplomacy Forum of Ukraine was held on June 2, 2015 at the Diplomatic Academy of Ukraine. The event was the brainchild of the Foreign Affairs Ministry and intended as a platform for interaction between all stakeholders involved in promotion of the Ukrainian cultural product in the world and supporting Ukraine's integration into the global cultural space. During the Forum, Minister of Foreign Affairs of Ukraine Pavlo Klimkin announced the establishment of a special department at the Foreign Affairs Ministry, focused exclusively on matters of cultural diplomacy. "For the first time cultural diplomacy appears in the structure of the Foreign Affairs Ministry as a holistic concept. This department will be integrated into the operations of the Foreign Affairs Ministry in the sphere of Ukrainian international communications. This synergy should yield results. 
Cultural projects will be an integral part of our efforts to explain to the world what Ukraine is and what it wants. Art communicates not just images, but meanings" (Ministerstvo zakordonnykh sprav Ukrainy, 2015a).

This idea has been implemented on December 22, 2015 when the Office of Public Diplomacy of the Ministry of Foreign Affairs of Ukraine was established. The main tasks of the Office have been defined as follows: development of relations with the public, civil society groups and the media in other countries and in Ukraine; carrying out projects focused on promoting Ukrainian image, culture and related information abroad; coordination of activities of other executive bodies in these domains (Ministerstvo zakordonnykh sprav Ukrainy, 2015b). As can be seen, the newly formed division is responsible for a wide range of activities in which cultural diplomacy is only one of the directions. Such approach seems justified as implementation of a public diplomacy strategy focusing overmuch on only one of its vectors would likely not have the desired effect. In addition, as noted above, the traditional practices of cultural diplomacy include the creation of special-purpose separate institutions.

However, cultural diplomacy as an independent direction has not disappeared from the agenda of the Ukrainian foreign policy. Thus, during the Second Cultural Diplomacy Forum of Ukraine, held on April 27, 2016 the participants - including Ukrainian and American diplomats, experts of the Kyiv Office of Kennan Institute and the "Global Ukrainians" NGO - have developed several recommendations for boosting Ukrainian cultural diplomacy to a new level of efficiency and improved strategic planning. These recommendations started with acknowledging there is a need to develop a coherent strategy for Ukrainian cultural diplomacy, and that implementation of cultural diplomacy is impossible without proper communication with the public and private sectors. Cultural diplomacy requires investment in human resources, training, seminars, online training, etc. Projects of cultural diplomacy should have a clear and cohesive message. Ukrainian cultural diplomacy should be aimed at multiplying the "capital" of sympathy of foreign audiences. Cultural diplomacy carried out by local Ukrainian diaspora should be actively encouraged by the state, while establishment of cooperation between local business and cultural environment will contribute to the successful export of Ukrainian products abroad (Ministerstvo zakordonnykh sprav Ukrainy, 2016).

Of note is also the initiative of the Ukrainian Ministry of Foreign Affairs to support cultural projects intended for foreign audiences. In December 2015, the Ministry had announced it was considering the possibility of using Internet as a platform supporting such projects. A selection of projects will obtain regular assistance in the form of expert services offered by the MFA. The financial aspect 
of the ministerial support would be quite limited; the focus was to be on information sharing and promotion, assistance in finding partners, recommendations, logistics and so on (Kulturna dyplomatiia Ukrainy vid MZS/Ukraine's Cultural Diplomacy by MFA, 2015).

\section{Birth of the Ukrainian Institute}

Following a proposal by the Ministry of Foreign Affairs, the Ukrainian government - in its resolution No. 430-r of June 21, 2017 - created the state institution "The Ukrainian Institute", subordinated to the MFA. The justification for this decision was the intent to protect state interests and to form a positive image of Ukraine abroad. The Institute was assigned the duties of disseminating and promoting the Ukraine's image around the world, facilitating international exchange and integration of Ukraine into the global cultural space, popularizing Ukrainian language and cultural products abroad, providing information about the scientific, educational and tourist potential of Ukraine etc. The Institute was set up as affiliated with the Ministry of Foreign Affairs, but independent in determining scope of its activities. A Supervisory Board was established to monitor the activities of the Ukrainian Institute and determine the strategic priorities in its activities. The Institute was to be financed partly from the state budget, as well as through charitable contributions and donor assistance (Kabinet ministriv Ukrainy, 2017).

According to its official statute, the purpose of the Institute's activities is to improve understanding and perception of Ukraine and Ukrainians in the world, to create a positive image of the state abroad. The key tasks of the Institute are: increasing Ukraine's recognition abroad through dissemination of knowledge about Ukraine; developing international dialogue by supporting international exchanges, ensuring Ukraine's participation in cooperative projects in all creative fields and culture, as well as education, science, economics and other spheres; sharing the Ukrainian experience in the development of civil society, state-building, progress in its commitment to the values of freedom, democracy, national unity; popularization of the Ukrainian language and culture abroad. To accomplish the tasks, the Ukrainian Institute uses multiple tools and formats: launches regular events to actively present Ukraine abroad (multidisciplinary and thematic festivals on Ukraine-related subjects, its language, culture etc.); conducts and supports events and programs aimed at informing foreign audiences of the cultural and socio-political life in Ukraine, development of its civil society, its tourist and edu- 
cational potential, as well as available opportunities and prospects of cooperation with Ukraine (Ministerstvo zakordonnykh sprav Ukrainy, 2017). In June 2018 in an interview the Director of the Ukrainian Institute, Volodymyr Sheiko, defined the list of countries for establishment of the Institute's branches: France, Poland and Germany were pointed out as first-priority destinations; with locations in Austria, Belgium, Italy, the USA, Turkey and the Czech Republic to added in the medium term (LB.ua, 2018).

\section{Cultural Diplomacy Initiatives beyond the Ministry of Foreign Affairs of Ukraine}

The long-lasting inertia of Ukrainian government in matters of cultural diplomacy has led to some (albeit rare) private initiatives trying to fill his gap. The most notable example is the Ukrainian Institute in Sweden, which was established in August 24, 2014 as a private initiative of Ukrainian pianist Natalia Pasichnik and the soloist of the Warsaw opera Olha Pasichnik. Its mission was to "put Ukraine on the cultural map of Sweden through cultural, educational and charitable activities", and the intended purpose was "to open up cultural Ukraine to the world" (Ukrainian Institute of Sweden, n.d.). Currently both these statements have disappeared from the Institute's website.

It should be noted that this initiative was supported by the Embassy of Ukraine in Sweden. The then-Charge d'Affaires of Ukraine in Sweden Ihor Tseluyko had commented that "Unfortunately, the state does not have enough funds to establish institutes of Ukrainian culture in Europe. However, the embassy supports the initiatives of individuals in this area. This time the event organized by Natalia Pasichnyk is supported by the diplomatic corps. Ukraine allocates money to some cultural programs, so we try to support the Institute established by Natalia Pasichnyk via public funds and the relations that the Embassy of Ukraine has developed" (Zhukov, 2014).

In addition, the then Minister of Culture of Ukraine Yevhen Nyschuk had declared his willingness to support the Ukrainian Institute in Sweden: "Such initiatives should be supported and elaborated on by further joint efforts for all the best ideas to be embodied in life. Moreover, support of such institutions should be done not by the means of symbolic gestures, but by the discussions of the specific tasks and propositions of solutions. We, as the Ministry of Culture are open to build effective mechanisms of cooperation, including fundraising, with the Foreign Ministry and other state institutions. This is especially important now, when 
the degree of interest in Ukraine is great, and the work of these centres is an important step in the cultural diplomacy" (Ministerstvo kultury Ukrainy, 2016).

Co-option of the Ukrainian Institute in Sweden into the framework of Ukraine's official foreign policy initiatives was formalised on July 17, 2015 when the Ministry of Culture of Ukraine, the Embassy of Ukraine in the Kingdom of Sweden and the Ukrainian Institute in Sweden signed a tripartite memorandum, declaring their joint intention to deepen Ukrainian-Swedish cultural cooperation through common goals, and to carry out informational and educational work aimed at promoting Ukrainian culture and art in Sweden. Such cooperation was to aid in formation of a positive image of Ukraine in Sweden and to stimulate interest in its national culture (ZIK, 2015).

\section{Conclusion}

The role of cultural diplomacy as an instrument of Ukrainian foreign policy can be summarised as follows.

1. Cultural diplomacy has been virtually absent in the foreign policy of Ukraine for a long time. The creation of cultural-informational centres as part of Ukrainian foreign diplomatic missions from 2006 onwards was only a shallow attempt to introduce a cultural dimension to the Ukrainian diplomatic practice. The operation of these centres has - inter alia due to understaffing - proven to be inadequate and lacking in substance, and did not contribute to formulating a true vision of the role of Ukrainian culture in its foreign policy. As a result, only a few centres have shown an active effort to promote Ukrainian culture in their host countries, to the credit of their employees showing own initiative.

2. Reconsideration of the role of cultural diplomacy and its thoughtful inclusion into Ukrainian foreign policy took place only following the "Revolution of Dignity". Focused discussions involving the public and experts, representatives of the Office of Public Diplomacy in the Ministry of Foreign Affairs of Ukraine helped to crystallize the idea of creating a special-purpose institution, based on the European best practices, with the objective of promoting Ukrainian culture abroad. At the moment it is too early to analyse the impact of institutional initiatives that followed, especially of the newly established Ukrainian Institute, but even the simple fact they exist and continue in their tasks is an important step forward for the Ukrainian foreign activities in the field of cultural diplomacy. 
3. Long-lasting lack of a comprehensive governmental perspective on cultural diplomacy has led to emergence of some private initiatives in this domain, the most remarkable of which is the Ukrainian Institute in Sweden. On the one hand, this example proves the high potential value of non-state stakeholders in promotion of Ukrainian culture in foreign countries, while also highlighting the historically deficient state participation in these processes.

\section{References:}

Ammon, R.J. (2001). Global Television and the Shaping of World Politics: Telediplomacy and Foreign Policy. Jefferson, NC: McFarland.

Cull, N.J., Culbert, D., Welch, D. (2003). Propaganda and Mass Persuasion: A Historical Encyclopedia, 1500 to the Present. Santa Barbara, CA: ABC-CLIO.

Gilboa, E. (2008). Searching for a Theory of Public Diplomacy. The ANNALS of the American Academy of Political and Social Science, 616, 55-77. DOI: 10.1177/00027162073 12142.

Ham, P. van (2010). Social Power in International Politics. Abingdon, Oxon: Routledge.

Hrachevska, T.O. (2016). Diialnist kulturno-informatsiinykh tsentriv yak komponenta kulturnoi dyplomatii. Hrani, 2(130), 22-26.

Kabinet ministriv Ukrainy. (2006). Perelik zakordonnykh dyplomatychnykh ustanov Ukrainy, u skladi yakykh utvoriuiutsia kulturno-informatsiini tsentry. Zatverdzhenyi rozporiadzhenniam Kabinetu Ministriv Ukrainy vid 19 kvitnia 2006 r. No. 213-r. Retrieved from: http://zakon4.rada.gov.ua/laws/show/213-2006-r.

Kabinet ministriv Ukrainy. (2017). Pro utvorennia derzhavnoi ustanovy "Ukrainskyi instytut": Rozporiadzhennia Kabinetu ministriv Ukrainy vid 21 chervnia 2017 r. No. 430-r. Retrieved from: https://www.kmu.gov.ua/ua/npas/250094619.

Kuchma, L. (2003). Ukrayna - ne Rossyia. Moskva: Vremia.

Kulturna dyplomatiia Ukrainy vid MZS/Ukraines Cultural Diplomacy by MFA. (2015). Druzi, komanda Kulturnoi dyplomatii Ukrainy vid MZS z pryiemnistiu povidomliaie, shcho vpershe vistorii vidomstva my stvoryly alhorytm pidtrymky ministerstvom kulturnykh proektiv, yaki realizovuvatymutsia za kordonom [Facebook post]. Retrieved from: https://www.facebook.com/CulturalDiplomacyUkraine/posts/1056919127662862.

LB.ua. (2018). Volodymyr Sheiko: 'Ukrainskyi instytut predstavliatyme interesy $i$ tsinnosti suchasnoi ukrainskoi politychnoi natsii'. Retrieved from: https://ukr.lb.ua/culture/2018/06/13/400222_volodimir_sheyko_ukrainskiy.html.

Ministerstvo kultury Ukrainy. (2016). "Pidtrymka roboty Ukrainskoho instytutu u Shvetsii - vazhlyvyi krok u kulturnii dyplomatii" - Yevhen Nyshchuk. Retrieved from: http:// mincult.kmu.gov.ua/control/uk/publish/article?art_id=245095538.

Ministerstvo zakordonnykh sprav Ukrainy. (2015a). V MZS vidbuvsia Pershyi forum kulturnoi dyplomatii Ukrainy. Retrieved from: http://mfa.gov.ua/ua/press-center/news/ 37021-v-mzs-vidbuvsya-pershij-forum-kulyturnoji-diplomatiji-ukrajini. 
Ministerstvo zakordonnykh sprav Ukrainy. (2015b). V MZS stvoreno novyi napriam roboty - publichna dyplomatiia. Retrieved from: http:/mfa.gov.ua/ua/press-center/news/ 43433-v-mzs-stvoreno-novij-napryam-robotipublichna-diplomatija.

Ministerstvo zakordonnykh sprav Ukrainy. (2016). 27 kvitnia v Dyplomatychnii akademii pry MZS Ukrainy vidbuvsia Drubyi forum kulturnoi dyplomatii Ukrainy. Retrieved from: http://mfa.gov.ua/ua/press-center/news/47000-27-kvitnya-v-diplomatichnij-akademiji-pri-mzs-ukrajini-vidbuvsya-drugij-forum-kulyturnoji-diplomatiji-ukrajini.

Ministerstvo zakordonnykh sprav Ukrainy. (2017). Statut derzhavnoi ustanovy "Ukrainskyi instytut". Zatverdzheno Nakazom Ministerstva zakordonnykh sprav Ukrainy vid 6 hrudnia 2017 r. No. 540. Retrieved from: https://mfa.gov.ua/mediafiles/files/misc/201801-17/2018-01-23_n540_statute.pdf.

Nye, J.S. (2004). Soft Power: The Means to Success in World Politics. New York: PublicAffairs.

Ociepka, B. (2008). Public Diplomacy. In: W. Donsbach (ed.). The International Encyclopedia of Communication (pp. 3956-3960). Malden, MA: Blackwell Publishing.

Prezydent Ukrainy. (2006). Polozhennia pro kulturno-informatsiinyi tsentr u skladi zakordonnoi dyplomatychnoi ustanovy Ukrainy. Zatverdzhene Ukazom Prezydenta Ukrainy vid 20 liutoho 2006 roku No. 142/2006. Retrieved from: http://zakon4.rada.gov.ua/laws/show/ 142/2006.

Rohovyk, O. (2016). Oleksandra Saienko: "Avstriitsi duzhe chutlyvi do mystetstva ta kultury, tomu kulturna dyplomatiia u Avstrii tochno pratsiuie". Retrieved from: https:/global-ukraine.com/2016/01/oleksandra-sayenko-avstrijtsi-duzhe-chutlyvi-mystetstva-takultury-tomu-kulturna-dyplomatiya-u-avstriyi-tochno-pratsyuye/.

Rozumna, O.P. (2014). Optymizatsiia posylennia kulturnoi prysutnosti Ukrainy v Yevropi. Analitychna zapyska. Retrieved from: http://www.niss.gov.ua/articles/1522.

Serbina, N.F., Kuchmii, O.P. (2011). Kulturna dyplomatiia yak instrument zovnishnoi polityky suchasnoi yevropeiskoi derzhavy. Aktualni problemy mizhnarodnykh vidnosyn: Zbirnyk naukovykh prats, Vypusk 100 (Chastyna I), 122-131.

Ukrainian Institute of Sweden. (n.d.). Our mission - Ukrainian Institute of Sweden. Retrieved from: http://ukrainskainstitutet.se/en/our-mission/.

Ukrinform. (2015). Ukrainskyi kulturnyi tsentr u Paryzhi ocholyt Irena Karpa. Retrieved from: http://www.ukrinform.ua/rubric-culture/1896784-ukrajinskiy-kulturniy-tsentr-u-pariji-ocholit-irena-karpa.html.

Zhukov, A. (2014). U Shvetsii rozpochav robotu Ukrainskyi Instytut. Den. Retrieved from: http://day.kyiv.ua/uk/article/kultura/u-shveciyi-rozpochav-robotu-ukrayinskiyinstitut.

ZIK. (2015). U Shvetsii populiaryzovuvatymut ukrainsku kulturu. Retrieved from: http:// zik.ua/news/2015/07/17/u_shvetsii_populyaryzovuvatymut_ukrainsku_kulturu_ 608313. 